\title{
The function and institutional embeddedness of Polytechnics in the Indian education system
}

\author{
Sebastian Schneider and Matthias Pilz \\ University of Cologne, Chair of Economics and Business Education Herbert-Lewin-Straße 2, \\ 50931 Köln
}

Received: 02.12.2018, Accepted: 25.06.2019, Published: 19.12.2019

\begin{abstract}
Purpose: India's Polytechnics are a fundamental part of its (vocational) education and training system but are largely ignored in VET research. Understanding the status quo and potential of India's (vocational) education landscape requires an understanding of the role played by the Polytechnics, particularly in view of the Indian government's major efforts to implement a functioning VET system. Because little is known about the function and embeddedness of the Polytechnics the article therefore aims to examine how polytechnics are embedded in the Indian education and training system and what functions they perform for the actors within the system.
\end{abstract}

Methods: The article begins by describing the systemic embeddedness of Polytechnics in the Indian education system and demonstrates their role and function in relation to a range of stakeholder groups (individuals, employers, society and the economy). Problem-centred face-to-face interviews Interviews were conducted with the principals of 14 Polytechnics in Bangalore, Delhi and Mumbai, among other cities. Semi-standardized interview guidelines were used to conduct the interviews. The interviews were analyzed by qualitative content analysis.

Results: The results show that polytechnics perform various functions in the Indian education system. The Polytechnics teach both theoretical and practical skills, which is a special feature of the Indian system at this level. Qualification takes place at an intermediate level,

*Corresponding author: matthias.pilz@uni-koeln.de 
which means that graduates have the opportunity to enter a company after graduation, where they can hold a kind of supervisor position. It is precisely these employees that are increasingly being sought by Indian companies. In addition, polytechnics provide a pathway to higher education, so students can use the opportunity to switch to a college once they have their diploma at the Polytechnic. Furthermore, the Polytechnics offers its graduates a good opportunity to become self-employed through the wide range of specializations and the practice-oriented skill development. In addition, the Polytechnics offer numerous opportunities to promote socially disadvantaged groups.

Conclusion: The survey findings illustrate the importance of Polytechnics to the various stakeholder groups, demonstrating their "multidimensional bridging function" within the Indian education and training system.

Keywords: Polytechnic, india, institutional role, vocational education, skill development, vocational education and training, VET

\section{Introduction}

India faces a severe skills gap (King, 2012). Although trends in education have produced a substantial increase in the number university graduates, there is still a shortage of wellqualified mid-range workers (Majumdar, 2016). Employers are unable to find workers with the necessary skills and job seekers struggle to find a suitable job (Pilz, 2016). According to official data, $90 \%$ of companies are unable to meet their requirements for skilled workers and 89\% complain that this prevents them from fulfilling their market potential (Agrawal, 2012).

Saini (2015) warns that "India’s demographic dividend can rapidly convert into a demographic nightmare" if the Government fails to give the labour force relevant skills. Large numbers of young people cannot find a job because they lack the required skills, with a potential detrimental effect not only on the economy but also on society (FICCI, n.d.).

This forms the background to this article, which focuses on a key component of the Indian education and training system, the Polytechnics (abbreviated here to PTs). In purely quantitative terms, PTs are an important part of the Indian system as Mehrotra (2016) and Venkatram (2016) note, but little is known about their embeddedness and function. The article therefore considers how they are embedded within the Indian education and training system and what functions they perform for the actors within the system. Specifically, it seeks to establish which functions the institution performs for the actors (function) and where it sits within the vocational education system as well as how it is integrated into the Indian system (embeddedness). The article contributes to international research in three ways. First, it applies the theory of institutionalism to the Indian vocational training context: institutionalism provides a good explanatory pattern for the function and embeddedness of institutions in 
the area of VET. Second, it addresses the debate around the relevance of educational institutions, illustrating the relevance within the Indian system of the institution being considered (PT) and what role the institution performs within the system. Finally, the article widens the current research by focusing on PTs and the differences between them and, for example, Industrial Training Institutes (ITIs), which were not included in the study. This intensive focus on PTs thus contributes to furthering the research base.

The article begins with an overview of India's VET system, putting the PTs in a broader educational context.

It then outlines the research study, describing its theoretical framework and methodological approach. The findings shed light on the role of the PTs and on their embeddedness in the system. The article concludes with an evaluation and discussion of the findings.

\section{An overview of post-secondary education and vocational training ${ }^{1}$}

The Indian education system comprises primary education, secondary education, upper secondary education and higher education. Both secondary and upper secondary education (classes 9 to 12) last two years, but secondary education is solely school-based, whereas upper secondary education is provided "either in schools or in junior colleges" (Gupta et al., 2016). The secondary and upper secondary stages of education are considered very important, as this is when students must decide whether to undertake vocational training, start work or embark on higher education (Gupta et al., 2016).

The Indian VET ${ }^{2}$ system has two levels, the school level and the purely vocational level. At school level, $\mathrm{VET}^{3}$ starts at the upper secondary level (classes 11 and 12) in schools providing general education and lasts two years. School-based vocational education is the responsibility of the Department of School Education in the Ministry of Human Resource Development (Venkatram, 2012; Agrawal \& Indrakumar, 2014) 160 vocational courses in "agriculture, business and commerce, engineering and technology, health and paramedical [care], home science and science and technology" are taught at around 10,000 schools in India (Agrawal \& Indrakumar, 2014; Gupta et al., 2016). From an international perspective, this kind of education has a much more pre-vocational orientation than exclusively vocational orientation (Gupta et al., 2016; Pilz et al., 2014).

1 For a detailed account of the Indian VET system, including training, see Wessels \& Pilz (2018).

2 Although the terms vocational education and vocational training have different meanings in India, they are often used interchangeably in the literature. This article will follow suit and make no distinction between the two terms.

3 School-based VET is usually referred to in India as vocational education. 


\subsection{Industrial Training Institutes}

At the purely vocational level, $\mathrm{VET}^{4}$ is mostly provided by government-run ITIs and private Industrial Training Centres (ITCs) ${ }^{5}$ (Agrawal, 2012; Venkatram, 2012). The Directorate General of Training (DGT) ${ }^{6}$ in the Ministry of Skill Development and Entrepreneurship ${ }^{7}$ is in charge of the vocational training within higher education level. Training is provided under two schemes, the Craftsmen Training Scheme (CTS) and the Apprenticeship Training Scheme (ATS) (Agrawal \& Indrakumar, 2014; Gupta et al., 2016).

Under the Craftsmen Training Scheme, which was launched in 1950, ITIs were set up to meet the needs of the labour market (Sodhi, 2014). Following economic reforms, there was a great increase in their number in the 1990s, with the number of ITIs almost doubling between 1990 and 2000 from 2,137 to 4,274. Since 2000, the number of ITIs has grown even more rapidly. Most newly established institutions have been privately run ITIs whose number more than doubled from 2,772 in 2001 to 6,498 in 2010 (Joshi et al., 2014). The increase in government ITIs was not so marked, going from 1,727 in 2001 to 2,189 in 2010 (Joshi et al., 2014). By 2015, India had 11,964 ITIs (2,284 government-run ITIs and 9,680 private ITIs) offering training courses in 126 trades (DGT, 2015).

The duration of training offered by an ITI ranges from one to two years, depending on the course (DGT, 2015). Admission requirements stipulate that students must have completed either 8 or 10 years of school (Gupta et al., 2016). ITI courses are characterised by the dominance of theoretical over practical instruction. Some other quality problems like the low level of competence of teaching staff and out of date equipment were detected in a number of ITIs (Tara et al., 2016; Zenner et al., 2017).

On completion of the training programme, students receive National Trade Certificates (DGT, 2015). ITIs train "semi-skilled workers" (Venkatram, 2012). In order to be considered a skilled worker, ITI graduates must then complete an apprenticeship (Venkatram, 2012).

\subsection{Polytechnics}

PTs in India have attracted little attention from researchers despite their importance within the system. Most PTs in India offer courses in mainstream disciplines, such as civil, electrical and mechanical engineering, but over the last two decades, many PTs have started offering courses in other disciplines, including electronics, computer science, medical lab technology, hospital engineering and architectural assistantship. Many single technology institutions also

\footnotetext{
4 Within higher education, VET is usually referred to in India as vocational training.

5 In the literature, the terms government ITIs and private ITCs are used interchangeably. This article will follow suit and make no distinction between the two terms.

6 Former Directorate General of Employment and Training (DGE\&T) (DGT, 2017).

7 Former Ministry of Labour and Employment (DGT, 2017).
} 
offer diploma programmes in areas such as leather technology, sugar technology, printing technology etc. (Goel, 2011). Programmes in civil, electrical and mechanical engineering are, however, the most important and relevant, in terms both of student numbers and of their profile (Rao et al., 2014). The qualifications they offer are very important, as PTs are strongly associated with the 'diploma'. For example, in official statistics, PTs are often categorised as 'diploma-level technical institutions' and those completing courses are referred to as 'diploma holders' or, for example, as 'diploma engineers'. Most programmes - basic diploma courses - run for three years and are broken down into six semesters, but there are also many specialised programmes running for shorter periods. These programmes offer sub-degree diplomas, postgraduate diplomas and advanced diplomas, for example, along with part-time courses for students who are in employment. Students can complete the basic diploma and then immediately enrol for an advanced diploma, but other post-secondary students can also take the advanced diploma.

Admission to a PT requires successful completion of 10 years of general education or of a lower secondary TVET programme (UNEVOC, 2018). This means that the average age of entry is 16. Candidates also need to have passed the Secondary School Certificate (SSC) or its equivalent with an aggregate mark of at least 35\% (Rao et al., 2014). Selected programmes may also require 12 years of general education.

Training is mostly theoretical, but curricula also include practical elements, which enhance students' profile for vocational occupations. These practical elements are delivered, for example, in workshops within the institution and are intended as a way of practically applying the theoretical knowledge acquired ${ }^{8}$.

Following completion of a course and the award of a diploma, students are able to demonstrate specific skills, such as understanding and interpreting technical drawings, making cost calculations, or repairing and maintaining machinery (Goel, 2011).

India currently has 3,239 PTs (MHRD, 2018), a figure that has risen sharply over recent years as the government has placed increasing emphasis on vocational training (MoLE, 2017). More than 1.5 million students are enrolled at PTs, $83 \%$ of them male and $17 \%$ female. Student numbers are currently increasing substantially year on year (MHRD, 2016b), providing further evidence of the scale, relevance and importance of these institutions. PTs are relatively evenly distributed across states, although urban regions and metropolitan areas tend to have considerably higher proportions of such intuitions than rural regions (MHRD, 2016a). Special 'Community PTs' have been created to support the teaching of technical skills in rural areas and to promote development in these areas (MHRD, 2009). 'Women's PTs' are another special form of PT and focus on providing technical training for women. They often have a more specialised profile than mainstream PTs and aim to meet women's specific needs

8 For model curricula, see: https://www.aicte-india.org/education/model-syllabus\#. 
and aspirations, for example, they focus on labour market relevant subjects for women like design, fashion and beauty (Goel, 2011).

As higher education technical institutions, Indian PTs are structurally affiliated to the Ministry of Human Resource Development (MHRD). The All India Council of Technical Education (AICTE) administers and accredits PTs (AICTE, 2017), but the institutions themselves sometimes operate very differently from one state to another. The reasons include the federalist principle that underpins the Indian Union and the differences between states in terms of economic structure and training needs. The State Boards of Technical Education play an important part here, as they coordinate the activities of PTs within individual states. They also oversee final examinations and issue diplomas (Singh, 2011; Norric, 2006). Standardised federal-level accreditation by the AICTE does, however, mean uniformity in key aspects of the design of PTs. The AICTE also oversees curriculum design and standardisation of syllabuses (Mehrotra, 2016).

In terms of financing and legal status, there are three main groups of PTs. Some are private and finance all their costs themselves, meaning that they have to charge higher student fees. Others are trusts funded by non-profit or religious bodies; some of these PTs do not have AICTE recognition or accreditation because of poor quality, and their status is, therefore, marginal. A distinction is also made between government and government-aided PTs. Government-aided PTs have private status but receive substantial public sector funding, whereas government PTs are in public ownership and all their costs are met centrally.

PTs have a long history in India and were initially influenced by the British education system because of the country's colonial past. Following the 1937 Abott-Wood report, technical and vocational education in India was reorganised, with a drive to develop and expand the PTs. The first PT was set up in Delhi in 1941 (Singh, 2011). Over the years, there were then further reforms of PTs (including in 1959 by AICTE), with the main objective of improving quality. Over time, the number and breadth of courses on offer also expanded. Further major reforms included the introduction of post-diploma courses (Singh, 2011).

Vocational training in India faces a number of different challenges and problems related to PTs (Kotamraju, 2014). In some cases, for example, their equipment and infrastructure are inadequate to meet demand. Depending on their legal status, their financial basis is sometimes insecure and, in some instances, is inadequate to enable them to provide high-quality teaching. Inadequate training for teachers and other staff and outdated curricula are major problems for the Indian VET system and the PTs in particular. This makes it difficult to compare individual PTs with each other: the quality they offer is very different (Goel, 2011). 


\subsection{Colleges and universities}

Higher education institutions in India fall into three major categories - universities, colleges and stand-alone institutions - and over recent years, their number has risen rapidly (MoLE, 2017; Khare, 2016). The majority of Indian students are enrolled at one of more than 39,000 colleges, which are affiliated to a university and award degrees from that university. Some universities have several hundred affiliated colleges, which are, however, relatively autonomous in terms of what they teach and have only an administrative link with the university in question (DAAD, 2017). A distinction also exists between public and private universities (Khare, 2016).

The degrees awarded are Bachelor's, Master's and pre-Doctoral and Doctoral degrees (Wessels \& Pilz, 2018). There are marked differences between educational institutions in terms of quality (Khare, 2016). While, for example, Indian Institutes of Technology (IITs) carry out cutting-edge research, many other universities lag behind their international competitors.

Students wishing to gain admission to a tertiary-level educational institution must successfully pass the All India Entrance Exam. Most school-leavers attempt the test on completion of 12 years of education. Access to higher education continues to depend largely on socioeconomic status and tends to be confined largely to those living in urban areas (Wessels \& Pilz, 2018).

\section{Research focus and theoretical approach}

As noted above, the PTs are of great relevance to India's system of formal vocational education and training. Despite this, however, there is a shortage of research into this form of training. Understanding the role of PTs is central to appreciating the status quo and potential of India's (vocational) education and training landscape, particularly against the backdrop of initiatives to reorient and restructure the country's VET system. Policymakers and training experts regard this system as a key factor in reducing social inequality and improving the effectiveness of the Indian private sector (Majumdar, 2016). In this respect, the PTs can also contribute a part to the human-centred development of India with its implications, e.g. in relation to human rights, well-being and empowerment (McGrath, 2012).

This article therefore analyses the roles and functions of the PTs in relation to a range of groups within India's VET system. It also sheds light on the relationship between the formal part PTs play in the system and their systemic role.

In terms of systemic embeddedness, the focus is on the education system itself. This perspective differs from the immediate perspective of individual stakeholder groups. The systemic embeddedness of PTs brings together the claims and aspirations of all stakeholder 
groups with regard to the institution. The actual form of the institution also reflects the influence and power relationships of the stakeholder groups involved (see below). At the same time, the current education system reflects historical structures and therefore illustrates the negotiation processes through which stakeholder groups have passed (see below).

This line of argument reflects the tradition of "historical institutionalism" and is discussed in detail by Thelen (1999), Pierson (2004) and Bulmer (1998). On an eclectic basis, historical institutionalism explicitly addresses the origins, transformation and functions of institutions.

This shows that functions play a central role in historical institutionalism and help to answer the research question. In this school of thought, institutions are defined by their functions for rational and self-interested actors. Institutions exist, therefore, because they provide efficient solutions for actors. And this means that institutions arise, exist and evolve for a reason and fulfil a specific function with a specific benefit to actors. However, this may change over time as a result of interaction between actors. Interaction between actors and institutions is therefore central to considering institutionalism (Steinmo \& Thelen, 1992) (Historical) institutionalism argues that actors act according to their own self-interest. However, they do so within a previously defined framework of social institutions and norms. Social norms influence the preferences of the actors and, thus, their actions (Hall \& Taylor, 1996). In the Indian context in particular, social norms play a prominent role.

Furthermore, the origins of institutions are analysed primarily in terms of path dependency (Pierson, 2004), while change is addressed predominantly in terms of critical junctures (Mahoney \& Thelen, 2010). Both approaches offer insights into the formal attribution of functions to PTs.

Thelen (2004) turns the spotlight of historical institutionalism on skills development, which is helpful because, as vocational schools, Indian PTs form part of the country's skills development system. Thelen argues that skills development underpins development of other systems: "Vocational training institutions occupy a central role in most characterizations of the various political-economic systems [cited above] - and for good reason. Skills are associated with a variety of outcomes of interest to political economists" (Thelen, 2004, p.8). Thelen has also investigated the institutional origins of skills development in a range of countries (Thelen, 2004).

Busemeyer (2014) uses Thelen's historical institutionalism approach and refines it by combining it with the partisan approach, to sharpen the focus on the roles of institutions. He establishes an even more explicit link between the stakeholders within an institution and the functions of that institution.

The approaches outlined above illustrate clearly the fundamental importance of stakeholders in the origins and development of an institution as well as in its future functions.

To enable us to survey the stakeholders within PTs relevant to our research question, the article uses the approach of stakeholder analysis as part of stakeholder research (Fullan, 2007; 
Pilz, 2012). Specifically, it uses an analytical stakeholder model (Berger \& Pilz, 2009), which explicitly portrays the benefit and function components of a range of target groups specifically in the context of vocational training. This stakeholder model enables the functions of the PTs to be assigned to stakeholders and facilitates the description, formulation and evaluation of data collected. This model introduces the four stakeholder groups listed below, which form the basis for application of the typology to the Indian PTs.

\section{The individual}

Vocational training is a key component in an individual's financial independence and success. The individual benefits from robust training in terms of securing a good income and positive prospects for the future (CEDEFOP, 2011a).

\section{Employers}

Employers need workers with vocational skills to enable them to sell their products or deliver their services. They therefore benefit substantially from vocational training, which gives them access to knowledge, competencies and expertise that will add productive value to their company (CEDEFOP, 2011b).

\section{Society}

Vocational training is a practical way of reducing social inequality. It also develops general social values that encourage individuals to play an active part in social development (CEDEFOP, 2011b).

\section{The economy}

An efficient system of skills development and, hence, a functioning vocational training system are key to a nation's economic development. Skills development is one of the keys to the development of other, related, systems (Thelen, 2004), and the stability of an economy relies on having an effective skilled workforce (CEDEFOP, 2014). PTs are a basic part of India's vocational training system.

\section{Methodological approach}

The data collection approach may be described as qualitative and exploratory (Flick, 2014). Structured and problem-centred face-to-face interviews were conducted for the study. A total of 14 interviews were conducted over a period of four weeks with the principals of 14 local PTs. Principals were the obvious subjects to interview, because their management role gives them an overview of their institution and the interests of the stakeholders involved. Moreover, as intermediaries between the state agencies that set regulations and the teaching staff who have to implement these regulations, they bring together a number of aspects. 
Most of the interviews were in urban centres (including Bangalore, Delhi and Mumbai), where most PTs are based. The team also visited a rural PT and three Women's PTs in Delhi and Bangalore. The PTs included in the study were located in a range of states, taking account of the differences between states. The specific selection of PTs locally was determined by the willingness of the institutions to take part. Access to the institutions was organised in cooperation with local research partners.

To balance the responses of the PT principals and to contextualise them, two interviews were also conducted with the relevant authorities and State Boards in Bangalore and Delhi.

To guide and steer the interviews and discussions, a semi-standardised set of interview guidelines was drawn up in line with theoretical models, enabling interviewees to speak openly on the areas under discussion but also to expand on areas they considered important (Flick, 2014).

The guidelines were structured into three main categories, with several subcategories. Category A included a range of general questions about the PTs under consideration, such as their legal status and funding basis, the number of students they taught, and the educational programmes they offered. Category B included questions on the content orientation of PTs, their functional aims, and the socio-economic background and employability of their students, such as "Which careers do your graduates choose after graduation?". Category C, finally, focused on the embeddedness of the PTs and their comparison with other Indian educational institutions, asking questions such as "What are the specific structural characteristics of PTs in comparison to ITIs or colleges?”.

The principals participated voluntarily in the survey, with no material incentives to do so.

The interviews were recorded electronically so that a verbatim record could be obtained of the interviewees' responses. Most interviews took between 50 and 90 minutes, depending on how informative each interviewee was. The interviews were conducted in the principal's office as part of a visit to the PT, and in some cases, other faculty were present during the interviews. Interviewees were able to express themselves clearly in English, so the interviews were conducted in that language without the need for an interpreter. The guidelines were scrutinised by several local experts with regard to the cultural component.

Mayring's (2000) open analytical tool was used to analyse the data gathered and devise categories on the basis of qualitative content analysis. 


\section{$5 \quad$ Findings on functions and institutional embeddedness}

This section of the article sets out the findings of the interviews with PT principals in line with Mayring's (2000) approaches to qualitative content analysis. The categories (graduates' skills mix; graduates' skills level; PTs as a path to higher education; skills development for self-employment; a broad range of specialisation; and integration of socially disadvantaged groups) are derived from the material (semi-structured interviews with principals) and represent a simplification of the data to a manageable basic form. The categories reflect the major interview findings and help to extract relevant information from the responses given by PT principals.

The categories enable statements to be related to the various stakeholder groups (the individual, employers, society and the economy). The statements made by interviewees are assigned to the stakeholders from the stakeholder model. The statements made by interviewees, the categories and the stakeholders addressed enable the functions of the PTs to be categorised according to stakeholder group in a subsequent stage. This then leads finally to identification of the embeddedness of PTs within the education and training system.

\subsection{Graduates' skills mix}

The principals reported that diploma holders, like ITI graduates, are considered blue-collar workers but actually carry out a supervisory role. They have an understanding of problems and a critical view of their profession:

"They can express and communicate, but they also have hands-on skills."

(DP4: PT principal from Delhi)

These hands-on skills are, according to the principals, what distinguish PT graduates from engineers with degrees and make them very attractive to potential employers. Companies need employees who not only have a solid theoretical foundation but can also operate the machinery. The principals also argued that diploma holders have an advantage over college graduates, whose knowledge is wholly theoretical, because the practical elements in their curriculum are a key building block. The State Boards maintain contact with representatives of industry and adapt PT curricula to the needs of employers. The problem orientation that helps diploma holders to take a practical approach to solving complex technical problems is a further aspect distinguishing them from ITI graduates, said the principals: the mix of solid theoretical knowledge and practical know-how gives them a decisive edge. This suggests some conclusions about the status of PTs within the education system: they are viewed as part of vocational training because they teach practical vocational skills but they also teach 
theoretical knowledge and so provide a (pre-)academic training. Most PT graduates find employment in small and medium-sized companies:

"The practical part really adds to the profile of diploma holders compared to others." (MP4: PT principal from Mumbai)

PT principals also alluded to the abilities of diploma holders to learn and adapt on the job. The assumption is that after two or three years' experience in industry, they are just as productive as college graduates. From companies' perspective, recruiting a diploma holder offers the further advantage that these individuals have lower salary expectations than degree-level engineers yet perform very well.

\section{Functions from a stakeholder perspective:}

The responses of the principals illustrate the added value for the individual of a PT training in terms of acquiring both theoretical and practical vocational skills.

Indian companies also benefit from this skills mix. This combination of high-level theoretical and practical knowledge is unique within the Indian education system (see Norric, 2006) and is a valuable resource in practice: PT graduates serve as a crucial interface within a company and bridge the gap between college graduates in management roles and manual employees with ITI qualifications. Employers have a particular interest in PTs because these institutions equip workers with both theoretical and practical knowledge.

\section{Systemic embeddedness:}

The PT produce graduates with both theoretical and practical knowledge, a unique characteristic at this level of the Indian education and training system. ITIs teach almost exclusively practical skills - and at a low level - while colleges teach solely theoretical academic knowledge (Mehrotra et al., 2014).

\subsection{Graduates' skills level}

Interviewees regarded the PTs as a link between different parts of the education and training system and saw their role as that of producing trainees with a competency level above that of those with ITI qualifications. ITI trainees carry out standardised craft roles or basic industrial roles, whereas the focus in PTs is on developing higher-level blue-collar skills. Once employed in companies, diploma holders can take on supervisory positions, reflecting their superior place in the hierarchy over ITI graduates. Interviewees argued that diploma holders are responsible for monitoring and supervising production processes and, therefore, the work of subordinate ITI graduates. In the internal hierarchy, diploma engineers occupy 
a superior position to ITI graduates but rank below college graduates, who tend to focus on planning, organisation and management roles.

In the view of the principals interviewed, the aim of the PTs is to produce employees with high skills levels. Those who have undergone PT training should demonstrate not only practical skills but also an awareness and understanding of problems that helps them critically to deploy the specialised skills required for their role. And this, the principals argued, distinguishes diploma holders from ITI graduates:

"The education in an ITI is on a lower level than [in a] PT. The ITI wants to educate semiskilled workers for the shopfloor while diploma holders work on a supervisor level."

(MP1: PT principal from Mumbai)

Nevertheless, argued the principals, Indian society persists in its view that academic training can provide high-level skills - what Indians still regard as the "measure of all things" (Jambo \& Pilz, 2017). As a result, there is evidence of a push towards academic training, with PTs being regarded as second-best, especially in the area of engineering. Despite this, the competency levels of diploma holders confer a range of advantages on the labour market, according to the principals:

"They work with [their] hands, which is not possible with degree graduates from College because they work as white-collar [workers]."

(MP1: PT principal from Mumbai)

\section{Functions from a stakeholder perspective:}

Individuals with PT qualifications benefit by being able to select a training institution that offers them an opportunity to develop intermediate-level skills. The skills and expertise they acquire at a PT enable them to find appropriate employment in a company.

Companies' needs for employees with skills profiles tailored to their activities are, therefore, being met through the skills that PT graduates bring to the labour market. PTs supply Indian companies with mid-range skills that enable these companies to meet their production or service requirements. The companies therefore view the PTs as a source of skilled labour.

\section{Systemic embeddedness:}

Statements made by the principals show clearly that in terms of its ability to train workers for the labour market, India's VET system has three levels of skills preparation. This is borne out by the work of Rao et al. (2014). Low-level manual shopfloor roles are filled by unskilled or semi-skilled workers with ITI training, while college graduates fill white-collar roles. Bridging the gap between these two groups are those who have a PT training. No other 
educational or training institution within the Indian system offers training at the same specific skills level as PTs.

\subsection{Polytechnics as a path to higher education}

The principals interviewed argued that many trainees regard PTs as merely a way-stage on the path to a college education, noting that increasing numbers of young people are taking up this route:

"Many students go to engineering college after they graduate here." (BP2: PT principal from Bangalore)

The principals identify a number of reasons. First, society continues to regard academic training as the "gold standard", with vocational education viewed as second-best. The reasons for this lie in the nature of Indian society and have been the subject of intensive debate (Mehrotra, 2012).

The VET system in engineering also offers some porosity. As a result of their upward mobility, diploma holders can enter directly into the second year of an engineering degree course (MSDE, 2016). The original pattern of $10+2+4$ years (general secondary + higher secondary + college (degree)) therefore becomes $10+3+3$ (general secondary + polytechnic (diploma) + college (degree, with direct entry to year two) as students skip the senior secondary examination, usually taken after 12 years of education, and move to a PT after 10 yefars and the SSC. Once at a PT, students acquire initial theoretical and practical training in engineering, preparing them better for a college course in engineering than the typical $10+$ $2+4$ year pattern (MSDE, 2016):

"I recommend to do $10+$ diploma, then degree [from] second year. We give them a lot of hands-on experience which doesn't come in $10+2$ - physics, chemistry, experience in engineering and other things."

(DP3: PT principal from Delhi)

\section{Functions from a stakeholder perspective:}

The statements from PT principals show clearly that individuals benefit particularly from this approach. By attending a PT, graduates acquire not only a vocational qualification but also the opportunity to switch to a college once they have their diploma. This function of PTs also illustrates the potential porosity between training courses and routes. Smooth transitions between different types of training underpin a functioning education and training system that benefits not only the individual but also society generally (Tuck, 2007). 
Against the background of institutionalism theory, the results clearly show that actors act according to their self-interest: individuals maximise benefits to themselves by achieving the highest educational attainment, which is recognised and valued within their social environment. This demonstrates that PTs are increasingly perceived as a route to higher education and less as a means of obtaining a supervisor-level job in the labour market.

\section{Systemic embeddedness:}

The responses of the principals demonstrate that successful students have the opportunity not only to access the labour market but also to move to a higher training institution (a college). This gives PTs a bridging function and enables diploma holders to go on to further academic training. Those successfully completing an ITI course can also move on to a PT.

\subsection{Skills development for self-employment}

The PT principals made it clear that alongside employment in a company or further study at a higher education institution, graduates have a further opportunity. Many PTs view their role as training students to move into self-employment. Graduates, too, see self-employment as a realistic and meaningful option on completion of their diploma. Trainees at other types of institution, and even those without formal qualifications, can of course opt for self-employment, particularly in India's sprawling informal sector, but diploma holders see this route to running their own business as particularly meaningful because of the broad practical and theoretical training they receive (see above), which makes them highly competitive commercially and opens up long-term market opportunities:

"Many students choose to be self-employed after they leave our PT. They can easily use their skills which they acquired from us on the market."

(BP3: PT principal from Bangalore)

This is particularly relevant to courses delivering skills that lead relatively easily to self-employment, such as courses at women's PTs in interior design, beauty culture and tourism:

"Lot of girls want to be self-employed, because the courses they choose match well with selfemployment."

(MP4: PT principal from Mumbai)

Running their own business is also, however, a popular choice for both male and female PT students. The particular emphasis of PTs, which offer a range of courses and link theoretical and practical knowledge, makes it especially attractive for PT graduates of both genders to pursue self-employment. 


\section{Functions from a stakeholder perspective:}

Two main stakeholder groups benefit from skills for self-employment. The first is individual students: self-employment represents a further option on the Indian labour market, which is particularly important given the country's large informal sector (Pilz et al, 2015; Pilz \& Wilmshöfer, 2015, Schneider \& Pilz, 2018). The solid theoretical and practical training that PT graduates receive enables them to earn an adequate income from self-employment, unlike many who are self-employed within India's informal sector (Pilz et al., 2015).

This aspect also benefits the economy as a whole. Self-employment brings graduates onto the labour market and helps reduce high levels of youth unemployment (ILO, 2016) as well as creating new (micro-)businesses that contribute to India's economic development.

\section{Systemic embeddedness:}

Other types of institution, such as ITIs, also claim to build skills for self-employment. However, PT graduates appear to benefit from improved prospects of success if they embark on this route. This may reflect the link between theoretical and practical skills, which is particularly important for self-employment. As noted above, this link is much less marked in both ITI and college courses.

\subsection{A broad range of specialisation}

Indian PTs offer a wide range of specialisation, including hotel management, food production, banking management and renewable energy. By providing training for staff in a range of sectors, the PTs are helping to keep the private sector flexible:

"We offer courses in our PT no-one else is offering in this area."

(BP1: PT principal from Bangalore)

If the private sector has access to a pool of staff with differing areas of specialisation, it will be able to react to the changing face of the economy. The relatively short duration of courses (mostly three years) means that companies can react quite quickly to economic change, and PTs are often the only institutions to offer certain specialised training. They also specialise in target interest groups (e.g. women). Nevertheless, the most popular courses at PTs remain those in technical, mechanical and electrical engineering, although the principals interviewed alluded to a tangible change in demand for non-technical vocational courses:

"We feel that there is a shift in the economy to the service sector. We [have been] offering courses in business and services for a long time and are able to widen them."

(MP3: PT principal from Mumbai) 
Meanwhile, courses are now being offered in highly-specialised fields, such as ceramics technology and photography, to meet growing niche requirements from the private sector.

\section{Functions from a stakeholder perspective:}

The diverse range of course on offer within PTs benefits the private sector and employers particularly. Unlike other training institutions, PTs often operate within training niches and are an important source of skilled labour for private sector companies. Without the skills of graduates in this wide range of subjects, companies in many specialised areas would struggle to recruit trained staff. Indian employers benefit, too, from significantly shorter induction and on-the-job training times.

\section{Systemic embeddedness:}

PTs offer the Indian training system a wide range of specialised courses that are not available in other institutions. College courses, for example, are often more general and have a less specialised focus, so induction periods for college graduates are longer.

\subsection{Integration of socially disadvantaged groups}

India's PTs help to integrate a number of different social groups, such as those living in rural areas. The Community Development through PTs (CDTP) programme has set up a number of PTs whose profile is tailored to the needs of rural populations with the stated aim of improving their skills and promoting rural development (MHRD, 2009).

The country also has many Women's PTs, whose profiles are tailored to female students and take account of gender-specific occupational profiles and needs, for example through courses in areas including early childhood education, fashion design and library sciences. As part of the data collection for the study, the project team visited a number of different Women's PTs. The individual profile of these institutions, argued the principals, promotes development among female students and helps them acquire a solid training in areas not offered elsewhere (Goel, 2011):

"Our [Women's] PT helps the girls to develop sufficient skills in the fields of their own interest." (DP1: PT principal from Delhi)

Statements by the principals make it clear that many students from the lower and middle social strata attend PTs. Many PT graduates are also the first in their family to enter higher 
education, which - say the principals - promotes porosity between social classes and social integration:

"Many of our students are the first in their family to be at a higher education institute."

(DP2: PT principal from Delhi)

PTs therefore help to support a range of socially disadvantaged groups in their development by offering them opportunities to acquire solid vocational skills.

\section{Functions from a stakeholder perspective:}

Individuals from diverse marginal social groups are advantaged by having the opportunity to attend a training institution such as a PT.

Meanwhile, integrating diverse population groups also strengthens social cohesion. PTs enable students from a range of social classes and groups to obtain good training, helping to integrate them in society.

\section{Systemic embeddedness:}

In a fragmented society like India in particular, where membership of a particular religious group, caste or gender can result in substantial disadvantage (Bhagavatheeswaran et al., 2016), the role played by PTs in social integration is vital. There is some limited evidence that ITIs also contribute to social integration, but little evidence within colleges. Unlike these other types of institution, PTs offer particular opportunities to socially disadvantaged groups, such as through community and Women's polytechnics. Moreover, while colleges formally set out to integrate a range of socially disadvantaged groups, this often proves difficult, for example self-selection by students (Arulmani \& Nag-Arulmani, 2006).

\section{Discussion: are Indian Polytechnics the "hidden champions" of the education system?}

To systematise these findings as functions of PTs requires recapping some of the key factors of the education and employment system in India. The first is the trend towards higher-level qualifications. Completing a course of academic study enjoys very high recognition in Indian society, whereas vocational training is regarded as second-best or even discounted entirely (Agrawal \& Agrawal, 2017).

Second, manual occupations are associated in India with dirty and dangerous working environments, poor pay and poor prospects (Tilak, 2002). These jobs tend to be reserved for individuals from lower castes (Arulmani \& Nag-Arulmani, 2006). 
Third, India has an exceptionally large informal economy, in which skills development is also often very informal (Sodhi, 2014; Sodhi \& Wessels, 2016) but that, in the case of larger employers, can require a certain level of specialist expertise.

Against this backdrop, PTs fulfil a kind of "multidimensional bridging function". Firstly, they bring together vocational training with elements of academic education, helping to reduce social stigma and signalling a valuable social reputation and recognition by companies and employers. Secondly, however, by linking practical and theoretical learning, they also meet the needs of Indian employers, who depend crucially on a supply of well trained and skilled workers with intermediate-level qualifications (Goel, 2011). Thirdly, the PT graduates themselves benefit, of course, but so too, particularly, SMEs because - unlike large companies - they cannot afford their own internal skills training systems (Mehrotra et al., 2014). The fourth and final aspect of this bridging function is that PTs offer their graduates excellent opportunities to set up a successful business within the informal economy on the basis of the skills a diploma gives them. This applies not only to young people from a privileged social background or higher castes but also to socially disadvantaged groups. By attending PTs, these groups are able to set up their own business, earn a living and rise up the social ladder. A range of stakeholder groups therefore benefit from the existence of PTs. As described in the institutionalism approach, the various functions illustrate the interests of different individual actors. However, institutional change also manifests itself when the preferences of an interest group change. From a historical perspective, it can be said that individuals are currently the dominant and most lasting influence on the transformation of functions through their choices concerning the use of PTs as a route to higher education.

The historical development of this decision by individuals therefore means that greater use is being made of PTs as a route into academic training to the detriment of their role as providers of skills for employers and the labour market.

The demand for PT education is steadily growing, as evidenced by the rising numbers of students, but potential applicants increasingly have a different focus, and their ambitions are changing. Loftier ambitions on the part of individuals can be explained by the improvement in opportunities as a result of political reform - including for socially marginalised groups and the rapid pace of social change as well as the strong focus on status and on an academic education as the "gold standard" in Indian society.

At the same time, there are indications that employers are seeing a decline in their influence on PTs, as they are increasingly having to compete for graduates. From the employers' perspective, one solution to this problem is to intensify contacts between employers and PTs, e.g. through the provision of internships or the increased inclusion of compulsory internships in companies in the curricula. This could strengthen both the influence of employers on the PTs and the role of PTs as a source of skilled labour. This illustrates that the functions 
described from a historical institutionalism approach are constantly changing as stakeholders' preferences evolve.

Despite the change in functions over time, the findings set out above clearly show that this kind of "multidimensional bridging functions" is confined to the PTs. Against a backdrop of systemic embeddedness on the one hand and the lack of social and academic regard for the PTs on the other, these institutions can truly be regarded as the "hidden champions of the Indian education system". Detailed analysis of statements by PT principals shows, however, that they make no differentiation in terms of the type of skills taught. At international level, schools have the role of promoting talent and careers (Ballantine \& Hammack, 2012), yet the principals interviewed did not touch on this area. The internationally recognised functions of education processes - e.g. selection, legitimation and socialisation (Meyer, 1977; Fend, 2002; Cheng, 1996) - are also missing, even indirectly, from the statements made by the principals despite the fact that the interview guidelines made provision for discussing these aspects. It also became clear during the study that principals take a very positive view of the form of their own institutions and do not mention critical aspects and problems, despite these being well known from the literature and despite the interview guidelines offering scope for critical comments (see 2.2). This can be explained by the fact that the principals want to defend their own school form and therefore avoid negative statements in front of researchers in order to avoid unfavourable changes in the school form from their point of view. This paradox has already been evident in other research projects in India (see Jambo \& Pilz, 2017, inter alia).

According to the principals interviewed, the central purpose of a PT is to provide skilled workers for the labour market. Meanwhile, before they begin their training, the majority of students want to gain rapid access to the labour market and quickly to be in a position to support their families financially, while many prefer to go to college after completing their studies at a PT.

The fact that the principals largely ignored the more general functions of the education system may well be attributable to the fact that their working routines require them to focus solely on the micro-level of local needs of stakeholders rather than, more abstractly, on the macro-level of the education and training system (Jambo \& Pilz, 2017).

\section{Conclusions}

The findings permit some conclusions regarding the embeddedness and functions of PTs within Indiaas VET system. It is clear, for instance, which functions PTs perceives for the actors (function), where the PTs are classified in the vocational training system, and how they are integrated into the Indian system (embeddedness). 
The stakeholder model was used to provide detail in the study, to analyse, structure and attribute the findings to the relevant actors and to establish the relationship with the theoretical approach of historical institutionalism. Nonetheless, the study cannot claim general validity because of its limited sample size. The sole focus on PT principals is a further limitation: it would be desirable to survey all stakeholder groups to broaden the basis. On the other hand, the study provides valuable insights into the PTs as an institution, enhancing understanding of them by presenting their functions from the point of view of different stakeholders and their embeddedness in the Indian VET system.

Principals felt that, overall, PTs fulfil a range of functions for a range of stakeholder groups. In this regard, they are systemically unique because of the "multidimensional bridging function" they fulfil. Against the backdrop of their low social and academic status, they can then be recognised as the "hidden champions of the Indian education system".

The findings described here are of interest not only to India but also, potentially, to other countries where the education system has similar structural and/or stakeholder functions.

The findings also demonstrate a need for further research, for example longitudinal studies, to generate detailed analysis of successful transitions by PT graduates to the Indian employment system.

\section{References}

Agrawal R., \& Indrakumar (2014). Role of vocational education in shaping socio-economic landscape in India. The Indian Journal of Industrial Relations, 49(3), 483-498.

Agrawal, T. (2012). Vocational education and training in India: Challenges, status and labour market outcomes. Journal of Vocational Education \& Training, 64(4), 453-474.

Agrawal, T., \& Agrawal, A. (2017). Vocational education and training in India: A labour market perspective. Journal of Vocational Education \& Training, 69(2), 246-265.

AICTE (All India Council for Technical Education).(2017). Approval Process Handbook 20172018. Retrieved from https://www.aicte-india.org/downloads/Final-Approval-Process-Handbook-2017_18.pdf

Arulmani, G., \& Nag-Arulmani, S. (2006). Work orientations and responses to career choices - Indian regional survey. Retrieved from http://www.thepromisefoundation.org/files/documents/WorccIRS-Part-1.pdf

Ballantine, J. H., \& Hammack, F. M. (2012). The sociology of education: A systematic analysis. Upper Saddle River, NJ: Prentice Hall.

Bhagavatheeswaran, L., Nair, S., Stone, H., Isac, S., Hiremath, T., Raghavendra, T., \& Beatie, T. S. (2016). The barriers and enablers to education among scheduled caste and scheduled tribe adolescent girls in northern Karnataka, South India: A qualitative study. International Journal of Educational Development, 49, 262-270. doi:10.1016/j.ijedudev.2016.04.004

Berger, S., \& Pilz, M. (2009). Benefits of VET. In U. Hippach-Schneider, \& B. Toth (Eds.), VET Research Report 2009 (pp. 6-49). Bonn: BIBB. 
Bulmer, S. J. (1998). New institutionalism and the governance of the single European market. Journal of European Public Policy, 5(3), 365-386.

Busemeyer, M. (2014). Skills and inequality: Partisan politics and the political economy of education reforms in western welfare states. Cambridge: Cambridge University Press.

CEDEFOP (European Centre for the Development of Vocational Training).(2011a). Vocational education and training is good for you: The social benefits of VET for individuals. Luxembourg: Publications Office of the European Union.

CEDEFOP (European Centre for the Development of Vocational Training).(2011b). The benefits of vocational education and training. Luxembourg: Publications Office of the European Union.

CEDEFOP (European Centre for the Development of Vocational Training).(2014). Macroeconomic benefits of vocational education and training. Luxembourg: Publications Office of the European Union.

Cheng, Y. C. (1996). School effectiveness and school-based management: A mechanism for developement. London: Falmer Press.

DAAD (German Academic Exchange Service) (2017). Indien: Daten \& Analysen zum Hochschulund Wissenschaftsstandort. Bonn: DAAD.

DGT (Directorate General of Training).(2015). Statistics: Brief note about Industrial training institutes. Retrieved from http://dget.nic.in/content/institute/key-statistics.php

DGT (Directorate General of Training).(2017). An overview of apprenticeship training scheme. Retrieved from http://dget.nic.in/content/innerpage/overview-apprenticeship-training-scheme.php

FICCI (Federation of Indian Chambers of Commerce \& Industry).(n.d). Skills development: Sector profile. Retrieved from http://ficci.in/sector/74/Project_docs/SectorProfile.pdf

Fend, H. (2002). Educational institutions and society. In P. B. Baltes, \& J. Featherman (Eds.), International Encyclopedia of the Social and Behavioral Sciences (pp. 4262-4266). Oxford: Elsevier Science.

Flick, U. (2014). An Introduction to qualitative research. Los Angeles: Sage.

Fullan, M. (2007). The new meaning of educational change. London: Routledge.

Goel, V. P. (2011). Technical and vocational education and training (TVET) system in India for sustainable development. Bonn: UNESCO-UNEVOC International Centre for Technical and Vocational Education and Training.

Gupta, V., Raman, C., \& Krisanthan, B. (2016). Secondary (9-10) and higher secondary (11-12) education: Preparation for the world of work. Secondary and higher secondary education in India. In M. Pilz (Ed.), India: Preparation for the world of work (pp. 41-64). Wiesbaden: Springer VS.

Hall, P. A., \& Taylor, R. C. R. (1996). Political science and three new institutionalisms. Political Studies, 44(5), 936-957.

ILO (International Labour Organization).(2016). India labour market update. Retrieved from https:// www.ilo.org/wcmsp5/groups/public/---asia/---ro-bangkok/---sro-new_delhi/documents/publication/wcms_496510.pdf

Jambo, S., \& Pilz, M. (2017). Perceptions of teachers in Industrial training institutes: An exploratory study of the attractiveness of vocational education in India. International Journal of Training Research, 16(1), 4-18.

Joshi, S., Pandey, G., \& Sahoo, B. K. (2014). Comparing public and private vocational training providers. In S. Mehrotra (Ed.), India's skills challenge: Reforming vocational education and training to harness the demographic dividend (pp. 86-128). New Delhi: Oxford University Press. 
Khare, M. (2016). Higher Education / University: Taking the skills march forward in India - Transitioning to the world of work. In M. Pilz (Ed.), India: Preparation for the world of work (pp. 103-140). Wiesbaden: Springer VS.

King, K. (2012). The geopolitics and meanings of India's massive skills development ambitions. International Journal of Educational Development, 32(5), 665-673. dOI:10.1016/j.ijedudev.2012.02.001

Kotamraju, P. (2014). The Indian Vocational Education and Training (VET) System: Status, Challenges, and Options. Community College Journal of Research and Practice, 38(8), 740-747.

Mahoney, J., \& Kathleen, T. (2010). Explaining institutional change: Ambiguity, agency and power. New York: Cambridge University Press.

Majumdar, S. (2016). Foreword: Reflections on opportunities and challenges of skills development in India. In M. Pilz (Ed.), India: Preparation for the world of work (pp. 7-14). Wiesbaden: Springer VS.

Mayring, P. (2000). Qualitative Content Analysis. Forum Qualitative Sozialforschung / Qualitative Social Research. 1(2), Art. 20. Retrieved from http://nbn-resolving.de/urn:nbn:de:0114-fqs0002204

McGrath, S. (2012). Vocational education and training for development: A policy in need of a theory? International Journal of Educational Development, 32(5), 623-631. doi:10.1016/j.ijedudev.2011.12.001.

Mehrotra, S. (2012). India's skill challenge: Reforming the vocational training system to realize the demographic dividend. Oxford: Oxford University Press

Mehrotra, S., Raman, R., Kumra, N., Kalaiyarasan, \& Röß, D. (2014). Vocational education and training reform in India - Business needs in india and lessons to be learned from Germany. Gütersloh: Bertelsmann Stiftung.

Mehrotra, V. S. (2016). NVEQF: Skill development under the National Skills Qualifications Framework in India: Imperatives and challenges. In M. Pilz (Ed.), India: Preparation for the world of work (pp. 281-310). Wiesbaden: Springer VS.

Meyer, J. W. (1977). The effects of education as an institution. American Journal of Sociology, 83(1), 55-77.

MHRD (Ministry of Human Resource Development).(2009). Scheme of Community Development through Polytechnics. Norms and guidelines. MHRD, New Delhi: Govt. of India.

MHRD (Ministry of Human Resource Development).(2016a). Educational statistics at a glance. MHRD, New Delhi: Govt. of India.

MHRD (Ministry of Human Resource Development).(2016b). All India Survey on Higher Education (2015-16). MHRD, New Delhi: Govt. of India.

MHRD (Ministry of Human Resource Development).(2018). All India Survey on Higher Education (2017-18). MHRD, New Delhi: Govt. of India.

MoLE (Ministry of Labour and Employment).(2017). Annual report 2016-2017. Retrieved from https://labour.gov.in/annual-reports

MSDE (Ministry of Skill Development and Entrepreneurship).(2016). Report of the committee for rationalization \& optimization of the functioning of the Sector Skill Councils. MSDE, New Delhi: Govt. of India.

Norric (Nordic National Recognition and Information Centres) (2006). Report on the system of education in India. Retrieved from https://norric.org/files/education-systems/India-2006.pdf

Pierson, P. (2004). The limits of institutional design. In P. Pierson (Ed.), Politics in time: History, institutions and social analysis (pp. 103-132). Princeton: Princeton University Press. 
Pilz, M. (2012). International comparative research into vocational training: Methods and approaches. In M. Pilz (Ed.), The Future of vocational education and training in a changing world (pp. 561-588). Wiesbaden: Springer VS.

Pilz, M. (2016). Introduction: Why India's focus on preparation for the world of work is highly relevant. In M. Pilz (Ed.), India: Preparation for the world of work (pp. 15-23). Wiesbaden: Springer VS.

Pilz, M., Berger, S., \& Canning, R. (2014). Pre-vocational education in seven European countries: A comparison of curricular embedding and implementation in schools. European Journal of Educational Research, 3(1), 25-41.

Pilz, M., Uma, G., \& Venkatram, R. (2015). Skill development in the informal sector in India: The case of street food vendors. International Review of Education, 61(2), 191-209.

Pilz, M., \& Wilmshöfer, S. (2015). The challenges of formal, non-formal and informal learning in rural India: The case of fishing families on the Chilika Lagoon. Prospects: Quarterly Review of Comparative Education, 45(2), 231-243.

Rao, K. S., Sahoo, B. K., \& Ghosh, D. (2014). The Indian vocational education and training system: An overview. In S. Mehrotra (Ed.), India's skills challenge: reforming vocational education and training to harness the demographic dividend (pp. 37-85). New Delhi: Oxford University Press.

Saini, V. (2015). Skill development in India: Need, challenges and ways forward. Abhinav National Monthly Refereed Journal of Research in Arts \& Education, 4(4), 1-9.

Schneider, S., \& Pilz, M. (2018). Demand-driven-Ansätze als Schlüssel zum nachhaltigen Kompetenzerwerb. Zeitschrift für internationale Bildungsforschung und Entwicklungspädagogik, 41(4), $35-39$.

Singh, G. (2011). A survey of resources and services of polytechnic college libraries of Punjab and Chandigarh. Amritsar, India: Guru Nanak Dev University. Retrieved from https://shodhganga. inflibnet.ac.in/handle/10603/7053

Sodhi, J. S. (2014). A Study of skill gaps in the informal sector. The Indian Journal of Industrial Relations, 49(3), 456-470.

Sodhi, J. S., \& Wessels, A. (2016). Informal learning: Education and skill development in India's informal sector. In M. Pilz (Ed.), India: Preparation for the world of work (pp. 81-102). Wiesbaden: Springer VS.

Tara, N., Kumar, S., \& Pilz, M. (2016). Quality of VET in India: The case of Industrial training institutes.TVET@Asia, 7, 1-7. Retrieved from: http://www.tvet-online.asia/issue7/tara_etal_tvet7.pdf

Thelen, K.A. (1999). Historical institutionalism in comparative politics. Annual review of political science, 2(1), 369-404.

Thelen, K. A. (2004). How institutions evolve: The political economy of skills in Germany, the United States and Japan. Cambridge: Cambridge University Press.

Thelen, K. A., \& Steinmo, S. (1992). Historical institutionalism in comparative politics. In S. Steinmo, K. A. Thelen, \& F. Longstreth (Eds.), Structuring Politics: Historical Institutionalism in Comparative Analysis (pp. 1-32). Cambridge: Cambridge University Press.

Tilak, J. B. G. (2002). Vocational education and training in Asia. In J. P. Keeves, \& R. Watanabem (Eds.), The handbook on educational research in the Asia Pacific region. Berlin: Kluwer Academic Publishers.

Tuck, R. (2007). An introductory guide to national qualifications frameworks: Conceptual and practical issues for policy makers. Geneva: ILO Publications. 
UNEVOC (International Centre for Technical and Vocational Education and Training).(2018). TVET country profile India. Bonn: UNESCO-UNEVOC International Centre for Technical and Vocational Education and Training. Retrieved from https://unevoc.unesco.org/wtdb/worldtvetdatabase_ind_en.pdf

Venkatram, R. (2012). Vocational education and training system (VET) in India. In M. Pilz (Ed.), The future of vocational education and training in a changing world (pp. 171-178). Wiesbaden: Springer VS.

Venkatram, R. (2016). (Technical) Colleges: Technical Education in India - The Strengths and Challenges. In M. Pilz (Ed.), India: Preparation for the world of work (pp. 81-102). Wiesbaden: Springer VS.

Wessels, A., \& Pilz, M. (2018). India. In Grollmann, P., Frommberger, D., Clement, U., Deißinger, T., Lauterbach, U., Pilz, M., \& Spöttl, G. (Eds.), International Handbook of Vocational Education and Training, 24(50), 1-112. Bonn: BIBB. Retrieved from https:/www.bibb.de/veroeffentlichungen/ de/publication/download/9574

Zenner, L., Kumar, K., \& Pilz, M. (2017). Entrepreneurship education at Indian Industrial training institutes: A case study of the prescribed, adopted and enacted Curriculum in and around Bangalore. International Journal for Research in Vocational Education and Training, 4(1), 69-94.

\section{Biographical Notes}

Sebastian Schneider, M.Sc. is a research assistant and PhD candidate within the Chair of Economics and Business Education at the University of Cologne. His research interests include international VET research with the focus on India as well as the perceived value of vocational education and training.

Prof. Matthias Pilz holds a qualification in commercial education and is Professor of Economics and Business Education at the University of Cologne. He is Director of the German Research Center for Comparative Vocational Education and Training (G.R.E.A.T.). His major research areas include international comparative research into vocational education and training, transitions between training and employment, as well as teaching and learning. 